\title{
Menilai Kompetensi Pengetahuan IPA dengan Instrumen Pada Topik Pengaruh Kalor Terhadap Perubahan Suhu dan Wujud Benda
}

\section{Ni Kadek Ary Noviyani ${ }^{*}$, I Made Tegeh ${ }^{2}$, I Nyoman Laba Jayanta ${ }^{3}$}

\author{
1,2,3 Program Studi Pendidikan Guru Sekolah Dasar, Universitas Pendidikan Ganesha, Singaraja, Indonesia
}

\section{ART ICLE IN F O}

Article history:

Received June 19, 2021

Revised June 20, 2021

Accepted October 24, 2021

Available online December 25, 2021

Kata Kunci:

Instrumen Penilaian IPA, Pengaruh Kalor

Keywords:

Science Assessment Instrument, Heat Effect

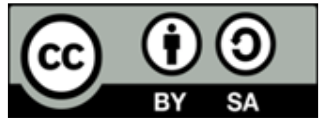

This is an open access article under the CC BY-SA license.

Copyright (c) 2021 by Author. Published by Universitas Pendidikan Ganesha.

\begin{abstract}
A B S T R A K
Guru mengalami kendala dalam pembuatan instrumen untuk menilai capaian belajar siswa yang berdampak terhadap rendahnya hasil belajar siswa khususnya pada kompetensi pengetahuan IPA. Tujuan penelitian ini adalah untuk mengembangkan dan menciptakan instrumen kompetensi pengetahuan IPA yang layak pada topik pengaruh kalor terhadap perubahan suhu dan wujud benda di kelas $\mathrm{V}$ sekolah dasar. Penelitian ini berjenis penelitian pengembangan dengan menggunakan model 4D yang terdiri dari empat tahap yang meliputi tahap pendefinisian (define), perancangan (design), pengembangan (development), dan penyebaran (disseminate). Pengumpulan data dalam penelitian ini menggunakan teknik wawancara, observasi, studi dokumen, dan metode tes berupa pilihan ganda. Data hasil penelitian kemudian dianalisis dengan uji validitas, uji reliabilitias, uji tingkat kesukaran, dan uji daya beda soal. Sebelum instrumen diimplementasikan kepada siswa terlebih dahulu dilakukan uji kepada ahli untuk membuktikan validitas isi instrumen. Hasil uji ahli menunjukkan sebanyak 34 soal relevan dan sebanyak 1 soal tidak relevan. Hasil implementasi kepada siswa menunjukkan instrumen memiliki validitas butir baik dengan 29 soal valid dan 5 soal tidak valid. Uji reliabilitas instrumen tergolong dalam kategori sangat tinggi dengan tingkat kesukaran sedang dan daya beda baik. Kesimpulan yang dapat ditarik berdasarkan hal tersebut adalah instrumen kompetensi pengetahuan IPA pada topik pengaruh kalor terhdaap perubahan suhu dan wujud benda valid dan layak digunakan untuk menilai capaian kompetensi pengetahuan IPA siswa.
\end{abstract}

\section{A B S T R A C T}

Teachers experience problems in making instruments to assess student learning outcomes which have an impact on student learning outcomes, especially in science knowledge competencies. The purpose of this study was to develop and create an appropriate science knowledge competency instrument on the topic of the effect of heat on changes in temperature and shape of objects in grade $\checkmark$ elementary school. This research is a development research using a $4 D$ model consisting of four stages which include the stages definition, design development, and dissemination. The data collection in this study used interview, observation, document study, and multiple choice test methods. The research data were then analyzed with validity tests, reliability tests, difficulty level tests, and different power tests. Before the instrument was implemented, the students were first tested by experts to prove the validity of the contents of the instrument. The results of the expert test showed as many as 34 relevant questions and 1 question irrelevant. The results of the implementation to students showed that the instrument had good item validity with 29 valid questions and 5 invalid questions. The reliability test of the instrument belongs to the very high category with moderate difficulty and good discriminating power. The conclusion that can be drawn based on this is that the instrument of science knowledge competence on the topic of the influence of heat on changes in temperature and object shape is valid and suitable to be used to assess the achievement of students' science knowledge competence. 


\section{PENDAHULUAN}

Pembelajaran muatan IPA pada jenjang sekolah dasar merupakan penanaman konsep-konsep dasar IPA untuk mengetahui lingkungan sekitar dan memecahkan masalah yang berkaitan dengan fenomena alam dalam kehidupan sehari-hari. Ketertarikan siswa dalam mengikuti proses pembelajaran memerlukan inovasi dalam merancang pembelajaran sehingga siswa memiliki minat dan motivasi untuk belajar. Capaian hasil belajar siswa dapat digunakan oleh guru sebagai dasar dalam perbaikan program dan proses pembelajaran IPA. Pada pembelajaran IPA seharusnya siswa aktif dalam pembelajaran serta diberikan kesempatan untuk mengalami dan menemukan sendiri tentang makna dari materi yang diajarkan ((Lusidawaty et al., 2020; Mahmud et al., 2018; Meo et al., 2021; Prananda et al., 2020). Pembelajaran IPA diharapkan dapat menjadi ajang bagi siswa untuk mempelajari dirinya sendiri dan alam sekitar, sehingga siswa dapat menerapkannya dalam kehidupan sehari-hari. Sesuai kurikulum 2013, pembelajaran IPA terdiri dari lima komponen yang meliputi materi, metode, strategi, media, dan penilaian (Kurniawati \& Mawardi, 2021; Mutmainna et al., 2018). Oleh karena itu, selain menciptakan pembelajaran yang dapat menumbuhkan motivasi siswa sangatlah penting bagi guru untuk membuat serta menggunakan instrumen penilaian hasil belajar siswa yang berkualitas khususnya dalam pembelajaran IPA. Instrumen yang digunakan harus tepat dan sesuai sehingga perlu dilakukan analisis sebelum dan sesudah digunakan agar menciptakan instrumen yang layak (Nufus et al., 2017; Setiawan et al., 2017; Widiyawati et al., 2019). Melalui penilaian yang dilakukan oleh guru dapat membantu siswa dalam mencapai tujuan pembelajaran (Arini et al., 2017; Adawiyah \& Wisudawati, 2017; Sudibyo et al., 2020). Jadi untuk meningkatkan kualitas pembelajaran muatan IPA, guru dituntut untuk menggunakan instrumen penilaian yang sesuai dengan standar penilaian yang telah ditetapkan.

Namun, pada kenyataannya instrumen penilaian kompetensi pengetahuan pembelajaran IPA yang digunakan guru selama ini memiliki kualitas yang rendah. Hal ini ditunjukkan dengan hasil PISA (the programme for international student assessment) pada tahun 2018 yang dipublikasikan oleh Organization for Economic Cooperation and Development (OECD) menyatakan bahwa kategori kemampuan sains Indonesia berada di peringkat ke 71 dari 79 negara partisipan PISA dengan skor rata-rata 389 yang berada di bawah skor rata-rata Internasional yakni 500 (Hewi \& Shaleh, 2020). Hal ini terjadi karena adanya masalah dalam pembelajaran IPA yang mengakibatkan rendahnya hasil belajar siswa. Salah satu masalah dalam pembelajaran IPA adalah penggunaan instrumen penilaian yang tidak sesuai dengan standar penilaian (Archer et al., 2013; Haka et al., 2019; Setiawan et al., 2017). Selain itu, berdasarkan hasil studi pendahuluan yang telah dilaksanakan menunjukkan bahwa hanya sebanyak $19,23 \%$ siswa yang tuntas dalam UTS IPA dan sebanyak $80,77 \%$ siswa belum tuntas. Hal ini menunjukkan tidak tercapainya tujuan pembelajaran yang telah ditetapkan. Kurangnya keinginan, kreativitas dan inovasi dari guru untuk merancang suatu instrumen pembelajaran memiliki pengaruh yang besar dalam membantu siswa mencapai tujuan pembelajaran (Krismony et al., 2020; Sudirman et al., 2020; Pettersson et al., 2015). Apabila hal ini dibiarkan tentunya akan mengakibatkan semakin rendahnya kualitas sumber daya manusia dan pembelajaran IPA di Indonesia di kemudian hari.

Upaya yang dapat dilakukan untuk mengatasi permasalahan tersebut adalah mengembangkan suatu instrumen penilaian kompetensi pengetahuan IPA sesuai dengan standar penilaian dan karakteristik siswa SD. Anditiasari \& Dewi (2021) menjelaskan teori Jean Piaget bahwa anak usia 7-12 tahun berada pada tahap operasi konkret yang mampu menggunakan operasi dan logikanya untuk objek yang nyata saja. Oleh karena itu, instrumen penilaian kompetensi pengetahuan IPA siswa SD dibuat dengan menyertakan gambar-gambar pendukung agar siswa secara nyata dapat mengamatinya. Instrumen penilaian merupakan suatu alat untuk mengumpulkan informasi mengenai hasil belajar siswa (Isnanto \& Kusdiwelirawan, 2020; Srirahayu \& Arty, 2018). Melalui penilaian dapat membantu guru dalam mengambil keputusan dalam perbaikan proses pembelajaran yang berdampak terhadap ketercapaian tujuan pembelajaran (Gustina et al., 2017; Mar'atus et al., 2018). Salah satu bentuk instrumen untuk menilai kompetensi pengetahuan IPA adalah instrumen tes berbentuk pilihan ganda yang merupakan alternatif untuk mengukur kemampuan berpikir kritis yang efektif dan efisien (Sari et al., 2019; Vinokurov et al., 2007). Instrumen penilaian berupa tes dalam pembelajaran sangat penting untuk mengumpulkan informasi terkait kompetensi pengetahuan IPA siswa sehingga guru dapat mengambil keputusan untuk memperbaiki efektivitas proses pembelajaran agar tercapainya tujuan pembelajaran

Instrumen penilaian kompetensi pengetahuan IPA siswa dibuat dengan memperhatikan syarat dari standar penilaian dengan analisis pada aspek validitas, aspek reliabilitas, aspek tingkat kesukaran, dan aspek daya beda. Instrumen penilaian harus disesuaikan dengan kompetensi yang akan dinilai dengan memenuhi syarat penilaian yang baik (Qureshi \& Ünlü, 2020; Yunita et al., 2017). Instrumen tes yang baik dan berkualitas hendaknya memenuhi syarat uji validitas, uji reliabilitas, uji tingkat kesukaran, dan uji daya beda (Imania \& Bariah, 2019; Nuroniyah, 2018; Pratiwi \& Fasha, 2015; Pratiwiningtyas et al., 2017). Instrumen penilaian kompetensi pengetahuan IPA tepat dikembangkan. Hal ini didukung oleh penelitian 
yang menghasilkan perangkat pembelajaran berupa instrumen penilaian yang baik dan layak digunakan untuk melakukan evaluasi pembelajaran (Oktharia et al., 2017). Instrumen penilaian kompetensi pengetahuan IPA yang dibuat berisi gambar agar sesuai dengan karakterisitik siswa SD yang berada pada tahap operasional konkret. Selain itu, tingkat kognitif dalam instrumen terdiri dari C1 sampai C6 yang tentunya dapat meningkatkan kemampuan berpikir kritis siswa. Tujuan dari penelitian ini adalah untuk mengembangkan dan menciptakan instrumen penilaian kompetensi pengetahuan IPA yang layak digunakan pada topik pengaruh kalor terhadap perubahan suhu dan wujud benda.

\section{METODE}

Jenis penelitian ini merupakan penelitian pengembangan instrumen penilaian yang dibuat dalam kompetensi pengetahuan IPA. Penelitian pengembangan ini memiliki tujuan untuk mengembangkan instrumen dan menghasilkan instrumen yang layak digunakan dalam pembelajaran IPA. Produk berupa instrumen yang dihasilkan dapat menyelesaikan permasalahan pembelajaran (Tegeh \& Kirna, 2013). Penelitian ini menggunakan model 4D yang memiliki empat tahap yaitu: (1) pendefinisian (define), (2) perancangan (design), (3) pengembangan (development), dan (4) penyebaran (disseminate) (Diani, 2015). Pemilihan model pengembangan ini didasari atas pertimbangan bahwa desain pengembangan model 4D ini penyajian modelnya dilakukan secara sederhana (Tegeh et al., 2019). Subjek penelitian ini adalah instrumen penilaian kompetensi pengetahuan IPA pada topik Pengaruh Kalor terhadap Perubahan Suhu dan Wujud Benda. Subjek penelitian akan diuji oleh ahli yang berkompeten dalam bidang muatan IPA.

Metode pengumpulan data yang digunakan dalam penelitian ini adalah wawancara, observasi, studi dokumentasi, dan metode tes berupa pilihan ganda. Wawancara dan observasi bertujuan untuk mengetahui permasalah terkait pembelajaran yang muncul di Sekolah Dasar. Studi dokumentasi bertujuan untuk mengetahui nilai UTS IPA siswa kelas V di SDN Kedisan Kecamatan Kintamani. Instrumen tes digunakan untuk mengetahui pemahaman siswa pada topik pengaruh kalor terhadap perubahan suhu dan wujud benda. Instrumen tes yang baik harus memenuhi uji validitas isi, uji validitas butir tes, uji reliabilitas, daya beda, dan tingkat kesukaran tes. Tahap yang dilalui untuk menhasilkan intrumen tes adalah adalah sebagai berikut, yakni: 1) Membuat kisi-kisi instrumen, 2) mengkonsultasikan kisi-kisi dengan dosen pembimbing, 3) menyusun instrumen. Kisi-kisi validitas instrumen terdiri dari 35 butir soal dengan ranah kognitif dari C3 sampai C6. Kisi-kisi intrumen tes Kompetensi Pengetahuan IPA yang meliputi kompetensi inti, kompetensi dasar, Indikator, ranah kognitif, nomor tes, dan jumlah soal. Yang termasuk dalam kompetensi inti yaitu memahami pengetahuan faktual, konseptual, prosedural, dan metakognitif pada tingkat dasar dengan cara mengamati, menanya, dan mencoba berdasarkan rasa ingin tahu tentang dirinya, makhluk ciptaan Tuhan dan kegiatannya, serta benda-benda yang dijumpainya di rumah, di sekolah, dan tempat bermain. Kompetensi dasar yaitu Menganalisis pengaruh kalor terhadap perubahan suhu dan wujud benda dalam kehidupan sehari-hari.

Indikator dari instrumen kisi-kisi ini yaitu 3.7.1 Menentukan sifat-sifat benda padat, cair, dan gas, 3.7.2 Menganalisis perbedaan sifat wujud benda (padat, cair, gas), 3.7.3 Menilai terjadinya peristiwa mencair, membeku, dan menguap, 3.7.4 Menentukan perpindahan kalor secara tepat, 3.7.5 Menentukan kalor dapat mengubah suhu benda, 3.7.6 Mengidentifikasi peristiwa penguapan dalam kehidupan seharihari, 3.7.7 Menetukan contoh benda pengantar panas/kalor dalam kehidupan sehari-hari, 3.7.8 Menentukan perubahan wujud benda yang dipengaruhi oleh kalor atau panas, 3.7.9 Merancang perubahan wujud benda yang dipengaruhi oleh kalor atau panas, 3.9.10 Mengidentifikasi peristiwa penyublin dalam kehidupan sehari-hari, 3.9.11 Menganalisis peristiwa pengkristalan dalam kehidupan sehari-hari, Menganalisis peristiwa pengembunan sebagai salah satu bentuk atau jenis perubahan wujud benda.

Sedangkan ranah kognitif dari kisi-kisi yang telah dibuat yaitu C3 / Konseptual C3 / Prosedural C3 / Metakognitif dengan nomor tes (1,23,16 dan jumlah soal 3 ), C4 / Metakognitif C4 / Prosedural C3 / Konseptual dengan nomor tes (2,11,14 dan jumlah soal 3 ), C5 / Prosedural C5 / Prosedural C5 / Metakognitif dengan nomor tes (7,8,17 dan jumlah soal 3 ), C3 / Prosedural C3 / Prosedural C3 / Prosedural dengan nomor tes (3,4,15 dan jumlah soal 3 ), C4 / Metakognitif C4 / Prosedural C3 / Prosedural dengan nomor tes (19,26,33 dan jumlah soal 3 ), C4 / Metakognitif C4 / Metakognitif C4 / Metakognitif dengan nomor tes (6,20, dan jumlah soal 3 ), C3 / Prosedural C3 / Prosedural C4 / Prosedural dengan nomor tes (12,13,24 dan jumlah soal 3 ), C3 / Metakognitif C3 / Prosedural C5 / Prosedural dengan nomor tes (10,25,30 dan jumlah soal 3 ), C6 / Metakognitif C6 / Metakognitif C6 / Metakognitif dengan nomor tes (27,28,29 dan jumlah soal 3 ), C4 / Prosedural C4 / Metakognitif C4 / Metakognitif dengan nomor tes (18,21,32 dan jumlah soal 3 ), C4 / Metakognitif C4 / Metakognitif C4 / Metakognitif dengan nomor tes (9,22,34 dan jumlah soal 3 ), C4 / Metakognitif C3 / Faktual C4 / Metakognitif dengan nomor tes (5,31,35 dan jumlah soal 3 ) 
Instrumen tes yang telah dibuat diuji coba oleh ahli untuk membuktikan validitas instrumen yang dikembangkan. Uji validitas isi intrumen menggunakan tabulasi silang dari rumus Gregory. Instrumen yang telah terbukti validitasnya kemudian diimplementasikan kepada siswa untuk memperoleh data berupa pemahaman kompetensi pengetahuan IPA siswa. Data yang dihasilkan dalam penelitian kemudian dianalisis validitas isi, validitas butir, reliabilitias, tingkat kesukaran, dan daya beda. Perhitungan validitas butir intrumen menggunakan rumus point biserial. Analisis reliabilitas intrumen menggunakan rumus dari Kuder Richardson. Analisis tingkat kesukaran menggunakan rumus indeks kesukaran butir soal. Analisis daya beda menggunakan rumus daya pembeda yang dilambangkan dengan huruf "D". Bagan desain pengembangan produk disajikan pada Gambar 1.

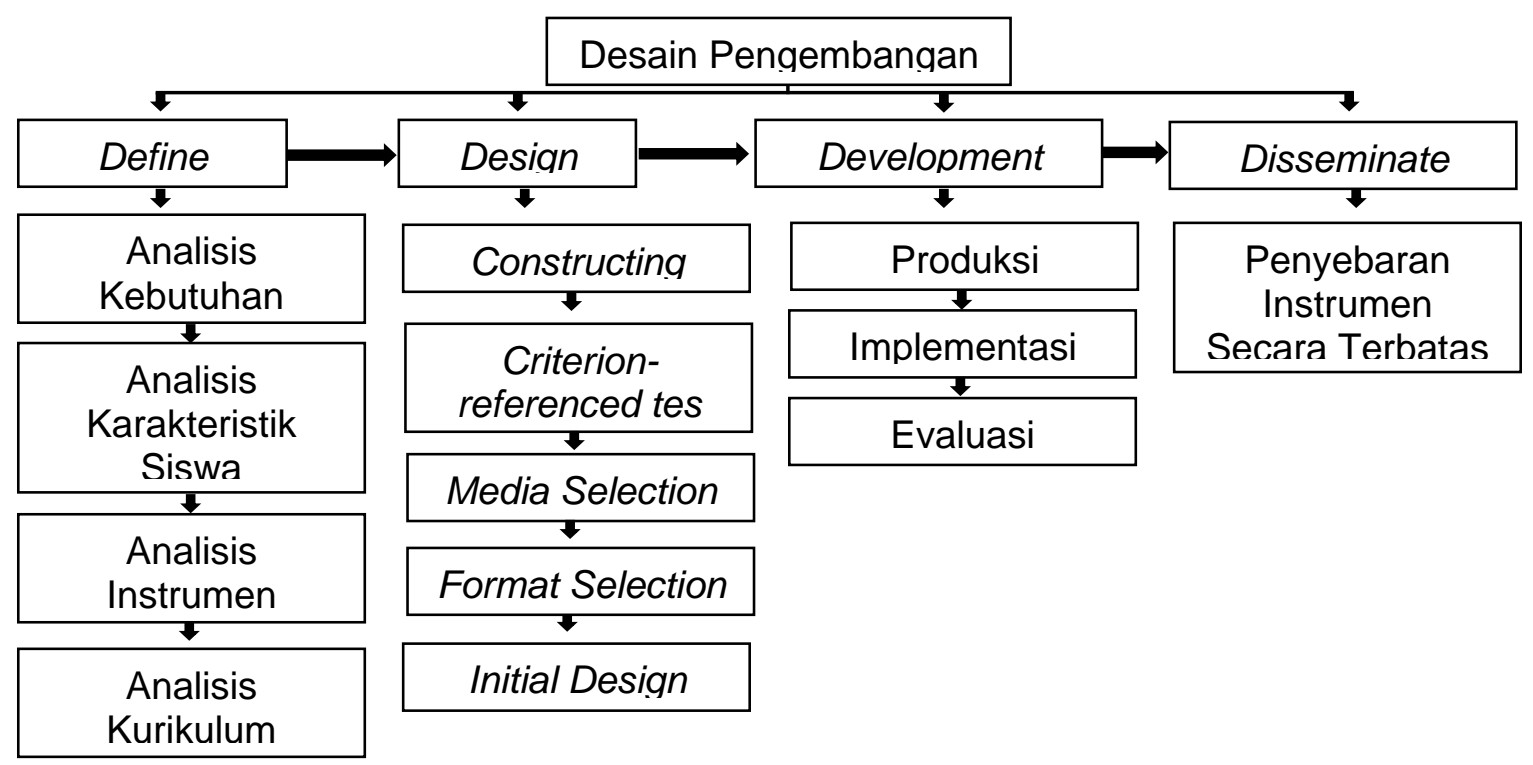

Gambar 1. Bagan Desain Pengembangan.

\section{HASIL DAN PEMBAHASAN}

Hasil

Penelitian ini merupakan penelitian pengembangan yang menghasilkan produk instrumen penilaian kompetensi pengetahuan IPA pada topik pengaruh kalor terhadap perubahan suhu dan wujud benda. Produk diujicobakan kepada dua dosen yang berkompeten di bidang muatan IPA untuk membuktikan validitas produk yang dikembangkan. Penelitian ini menggunakan model penelitian 4D yang memiliki empat tahap yaitu: (1) pendefinisian (define), (2) perancangan (design), (3) pengembangan (development), dan (4) penyebaran (disseminate). Adapun rancangan dari soal yang telah dibuat disajikan pada Tabel 1.

Tabel 1. Soal Pilihan Ganda

\begin{tabular}{|c|c|c|}
\hline No & Pertanyaan & Pilihan Ganda \\
\hline 1 & $\begin{array}{l}\text { Benda yang bentuk dan volumenya selalu tetap adalah wujud dari } \\
\text { benda ... }\end{array}$ & $\begin{array}{ll}\text { a. } & \text { padat } \\
\text { b. } & \text { cair } \\
\text { c. } & \text { gas } \\
\text { d. } & \text { cair dan gas }\end{array}$ \\
\hline 2 & $\begin{array}{l}\text { Anto ditugaskan oleh gurunya untuk melakukan sebuah percobaan } \\
\text { di rumah dengan menggunakan alat dan bahan berupa plastik dan } \\
\text { air. Kemudian Anto mengisi plastik dengan air dan menaruh plastik } \\
\text { yang sudah berisi air tersebut di dalam kulkas selama beberapa } \\
\text { menit, setelah beberapa menit Anto mengamati ternyata air yang } \\
\text { diwadahi pastik menjadi keras. Berdasarkan percobaan di atas } \\
\text { peristiwa perubahan wujud benda yang terjadi adalah ... }\end{array}$ & $\begin{array}{ll}\text { a. mencair } \\
\text { b. mengkristal } \\
\text { c. menyublin } \\
\text { d. membeku }\end{array}$ \\
\hline \multirow[t]{2}{*}{3} & $\begin{array}{l}\text { Benda yang tidak dapat kita lihat, tetapi dapat kita rasakan biasanya } \\
\text { merupakan sifat dari benda ... }\end{array}$ & $\begin{array}{l}\text { a. padat } \\
\text { b. cair }\end{array}$ \\
\hline & & $\begin{array}{l}\text { c. gas } \\
\text { d. padat dan gas }\end{array}$ \\
\hline
\end{tabular}




\begin{tabular}{cll}
\hline No & Pertanyaan & Pilihan Ganda \\
\hline 4 & Rina dan keluarga pergi berlibur ke Jepang ketika sampai di Jepang & a. mengkristal \\
& Rina menikmati turunnya salju dan Rina melihat tumpukan salju di & b. menyublim \\
& samping jalan kemudian Rina mengambil beberapa tumpukan salju & c. menguap \\
& yang terasa keras. Berdasarkan cerita tersebut contoh peristiwa & d. mencair \\
& perubahan wujud yang terjadi adalah ... & \\
Dewi menaruh kapur barus di lemari bajunya setelah beberapa hari & a. mencair \\
& $\begin{array}{l}\text { kapur barus tersebut ternyata semakin mengecil dan lama kelamaan } \\
\text { akan hilang. Berdasarkan peristiwa tersebut menujukan perubahan } \\
\text { wujud. }\end{array}$ & $\begin{array}{l}\text { b. mengkristal } \\
\text { c. menguap } \\
\text { d. menyublim }\end{array}$ \\
\hline
\end{tabular}

Sedangkan penjabaran mengenai hasil dari tahap-tahap pengembangan adalah sebagai berikut.

\section{Tahap Pendefinisian}

Tahap pendefinisian dilakukan melalui analisis kebutuhan, analisis karakteristik siswa, analisis instrumen yang sudah ada, dan analisis kurikulum. Analisis kebutuhan menunjukkan hanya sebanyak 19,23\% siswa tuntas dalam UTS IPA dan sebanyak 80,77\% siswa belum tuntas. Analisis karakteristik siswa SD menunjukkan bahwa siswa SD berada pada tahap operasional konkret yang membutuhkan guru untuk menyelesaikan tugasnya (Surya, 2018). Instrumen yang telah digunakan oleh guru selama ini kurang memperhatikan kemampuan yang dimiliki oleh siswa. Pada topik pengaruh kalor terhadap perubahan suhu dan wujud benda di sekolah dasar masih jarang dilakukan pengembangan instrumen penilaian. Berdasarkan tahap pendefinisian diperoleh bahwa instrumen penilaian kompetensi pengetahuan IPA pada topik pengaruh kalor terhadap perubahan suhu dan wujud benda di kelas $\mathrm{V}$ sekolah dasar sangat penting untuk dikembangkan.

\section{Tahap Perancangan}

Tahap perancangan dilakukan dengan constructing, criterion-referenced test, media selection, format selection, initial design. Constructing dilakukan dengan menyusun tes kriteria yang merupakan sebagai tindakan pertama dalam mengetahui kemampuan awal yang dimiliki oleh siswa. Criterionreferenced test dilakukan dengan memilih media pembelajaran yang tepat untuk materi maupun karakteristik yang dimiliki oleh siswa. Media selection dilakukan dengan memilih format sebagai bentuk penyajian dalam pembelajaran dan harus disesuaikan terhadap media pembelajaran. Initial design dilakukan dengan melakukan simulasi terkait penyajian media pembelajaran yang telah dirancang sebelumnya.

\section{Tahap Pengembangan}

Pada tahap pengembangan dilakukan melalui tahap produksi, tahap implementasi, dan tahap evaluasi. Tahap produksi merupakan proses membuat instrumen penilaian kompetensi pengetahuan IPA pada topik pengaruh kalor terhadap perubahan suhu dan wujud benda. Implementasi instrumen penilaian kompetensi pengetahuan IPA dilakukan uji coba secara terbatas kepada dua dosen ahli materi IPA dan 18 orang siswa kelas V SD. Implementasi kepada ahli dilakukan dengan memberikan instrumen penilaian kompetensi pengetahuan IPA yang telah dibuat beserta instrumen untuk diberikan penilaian. Implementasi kepada 18 orang siswa dilakukan dengan memberikan instrumen tes yang telah dibuat kepada siswa untuk mengetahui pemahaman kompetensi pengetahuan IPA siswa.

Berdasarkan uji validitas isi sesuai penilaian ahli menunjukkan dari 35 pertanyaan yang dikembangkan, sebanyak 34 pertanyaan yang relevan dan sebanyak 1 pertanyaan yang tidak relevan. Instrumen yang telah valid berdasarkan hasil uji coba kepada ahli kemudian diimplementasikan kepada siswa. Hasil dari implementasi siswa dianalisis dengan uji validitas butir, uji reliabilitas, uji tingkat kesukaran, dan uji daya beda. Uji validitas butir menggunakan rumus point biserial memperoleh $Y_{p b i}=$ 0,56 dan $\mathrm{r}_{\text {Tabel }}$ dengan responden yaitu 18 memiliki taraf signifikansi $5 \%$ adalah 0,468 . Dengan demikian hasil yang didapat hasil $r_{p b i}>r_{\text {Tabel, }}$, sehingga rekapitulasi hasil validitas butir 29 soal dinyatakan valid dan 5 dinyatakan tidak valid. Selanjutnya, uji Reliabilitas hanya dilakukan pada butir soal yang valid dengan menggunakan rumus dari Kuder Richardson. Berdasarkan hasil yang diperoleh, derajat reliabilitas instrumen yang dikembangkan yaitu sebesar 0,94. Dengan demikian, apabila dikonversikan ke dalam kriteria tingkat reliabilitias tergolong dalam kategori sangat tinggi. Setelah dilakukan uji reliabilitas dilanjutkan dengan uji tingkat kesukaran yang menunjukkan sebanyak 3 butir soal memiliki kesukaran dengan kategori mudah, sebanyak 31 butir soal memiliki kesukaran dengan kategori sedang, dan sebanyak 1 butir soal memiliki kesukaran dengan kategori sukar. Setelah uji tingkat kesukaran 
dilanjutkan dengan uji indeks daya beda yang menunjukkan bahwa tidak terdapat butir soal dengan kategori daya beda kurang baik, sebanyak 11 butir soal memiliki kategori daya beda cukup baik, sebanyak 21 butir soal memiliki kategori daya beda baik, dan sebanyak 3 butir soal memiliki memiliki kategori daya beda sangat baik. Setelah instrumen diimplementasikan dilanjutkan dengan evaluasi instrumen sesuai dengan masukan, saran, dan komentar dari ahli.

\section{Tahap Penyebaran}

Tahap penyebaran pada penelitian ini hanya sampai dengan tahap penyebaran terbatas saja dan tidak dilanjutkan dengan melakukan penyebaran secara meluas yang dilakukan di luar sekolah selain yang dijadikan tempat penelitian. Seperti kondisi saat ini yang menuntut setiap sekolah menerapkan sistem pembelajaran daring sehingga tidak memungkinkan untuk mengadakan pembelajaran tatap muka. Disamping itu juga disebabkan oleh keterbatasan waktu yang membutuhkan waktu yang cukup lama dan biaya yang tidak sedikit. Berdasarkan hasil analisis data yang telah diuraikan, maka dapat ditarik kesimpulan bahwa instrumen kompetensi pengetahuan IPA pada topik pengaruh kalor terhadap perubahan suhu dan wujud benda di kelas V sekolah dasar valid dan layak digunakan sebagai instrumen penilaian pada siswa kelas $\mathrm{V}$ sekolah dasar. Adapun faktor-faktor yang menyebabkan instrumen kompetensi pengetahuan IPA yang dikembangkan valid dan layak digunakan sebagai alat penilaian dalam proses pembelajaran, yang pertama yaitu karena instrumen yang dikembangkan telah memenuhi syarat instrumen penilaian yang baik. Hal penting yang menjadi suatu keharusan dalam membuat instrumen adalah beberapa uji sebagai syarat instrumen yang berkualitas. Pengembangan instrumen dalam penelitian ini dilakukan melalui uji validitas isi, uji validitas butir, uji reliabilitias, uji tingkat kesukaran, dan uji daya beda soal. Instrumen yang baik hendaknya memenuhi kriteria valid, reliabel, memiliki tingkat kesukaran yang sesuai dengan taraf kesukaran instrumen, dan memiliki daya beda (Pratiwi \& Fasha, 2015; Imania \& Bariah, 2019; Pratiwiningtyas et al., 2017). Selain uji pada instrumen, untuk menghasilkan instrumen yang berkualitas dilakukan revisi sesuai dengan masukan ahli yang berkompeten di bidangnya. Apabila dalam pembuatan instrumen tanpa dilakukan perbaikan atau revisi maka akan mengurangi kualitas dari intrumen yang dikembangkan (Arifin \& Retnawati, 2017; Julianingsih et al., 2017).

Selain dari faktor kesesuaian uji intrumen, pengembangan instrumen dalam penelitian ini menghasilkan instrumen kompetensi pengetahuan IPA pada topik pengaruh kalor terhadap perubahan suhu dan wujud benda yang dapat digunakan untuk memperoleh infromasi mengenai kompetensi pengetahuan IPA siswa. Penilaian sangat penting dilakukan guru dalam pembelajaran karena penilaian merupakan suatu cara untuk mendapatkan informasi terhadap kinerja siswa (Sylvia et al., 2019; Wirayasa et al., 2020). Instrumen ini dapat membantu guru dalam melakukan evaluasi sebagai pertimbangan perbaikan-perbaikan dalam proses pembelajaran yang dapat meningkatkan hasil belajar siswa. Evaluasi dalam pembelajaran adalah hal penting yang harus ditempuh guru untuk memperbaiki dan menyempurnakan program dan kegiatan belajar mengajar (Azizah et al., 2017). Instrumen yang dikembangkan telah disesuaikan dengan standar penilaian untuk dapat mengumpulkan dan melakukan analisis suatu data sebagai penentu ketercapaian hasil belajar siswa. Prinsip-prinsip berupa standar penilaian harus dikuasai dan diterapkan oleh guru karena mengandung prosedur, mekanisme, dan syarat instrumen yang baik sehingga dapat mempermudah penentuan capaian hasil belajar siswa (Hariono et al., 2021).

Penelitian ini didukung oleh penelitian yang menyatakan bahwa instrumen kemampuan berpikir kritis dan hasil belajar IPA siswa kelas V SD yang dikembangkan valid dan layak digunakan dalam kegiatan belajar mengajar (Amalia \& Susilaningsih, 2014; Oktharia et al., 2017; Wangsa et al., 2021). Selain itu, instrumen yang dikembangkan sangat penting dikembangkan dan memenuhi aspek validitas, reliabilitias, dan kepraktisan sehingga layak digunakan dalam pembelajaran (Ayu et al., 2018; Nafsih et al., 2020; Yoga et al., 2020). Sehingga dapat disimpulkan bahwa instrumen kompetensi pengetahuan IPA pada topik pengaruh kalor terhadap perubahan suhu dan wujud benda valid dan layak digunakan untuk mengukur kompetensi pengetahuan IPA siswa kelas $\mathrm{V}$ sekolah dasar. Keunggulan dari instrumen penilaian kompetensi pengetahuan IPA yang dikembangkan yaitu; (1) dapat mengidentifikasi kesalahan pemahaman konsep siswa pada materi pengaruh kalor terhadap perubahan suhu dan wujud benda (2) dapat memberi petunjuk letak kesalahan siswa, (3) mempermudah guru dalam mengumpulkan informasi hasil kompetensi pengetahuan siswa pada materi pengaruh kalor terhadap perubahan suhu dan wujud benda (4) dapat mengasah kemampuan siswa dalam materi pengaruh kalor terhadap perubahan suhu dan wujud benda. Sedangkan kelemahan instrumen penilaian kompetensi pengetahuan IPA yang dikembangkan yaitu; (1) hanya dapat menilai satu ranah yakni ranah kognitif (2) hanya dapat digunakan pada topik pengaruh kalor terhadap perubahan suhu dan wujud benda (Abbas, 2016). Implikasi penelitian ini adalah terciptanya instrumen penilaian kompetensi pengetahuan IPA pada topik pengaruh kalor terhadap perubahan suhu dan wujud benda yang dapat digunakan guru untuk menilai pengetahuan 
siswa pada ulangan harian maupun penilaian tengah semester. Disamping itu, intrumen yang dikembangkan dapat dijadikan pedoman peneliti lain maupun guru dalam merancang soal dengan kualitas yang baik dan untuk melakukan perbaikan dan evaluasi proses pembelajaran yang berdampak pada tercapainya tujuan pembelajaran.

\section{SIMPULAN}

Berdasarkan hasil analisis data yang diperoleh dari uji ahli dan implementasi secara terbatas kepada siswa menunjukkan instrumen valid dan layak digunakan dalam proses pembelajaran. Hal ini dapat ditinjau dari hasil analisis uji coba instrumen dari ahli yang menunjukkan instrumen telah memenuhi kriteria validitas isi. Selain itu, impelementasi instrumen kepada siswa menunjukkan bahwa instrumen yang dikembangkan telah memenuhi syarat instrumen yang baik ditinjau dari aspek validitas, reliabilitas, tingkat kesukaran, dan daya beda. Maka, instrumen penilaian kompetensi pengetahuan IPA pada topik pengaruh kalor terhadap perubahan suhu dan wujud benda valid dan layak digunakan dalam proses pembelajaran.

\section{DAFTAR PUSTAKA}

Abbas, M. L. H. (2016). Pengembangan Instrumen Three Tier Diagnostic Test Miskonsepsi Suhu dan Kalor. Ed-Humanistics, 01(02). http://ejournal.unhasy.ac.id/index.php/ed-humanistics/article/view/69.

Adawiyah, R., \& Wisudawati, A. W. (2017). Pengembangan Instrumen Tes Berbasis Literasi Sains : Menilai Pemahaman Fenomena Ilmiah Mengenai Energi. Indonesian Journal of Curriculum, 5(2), 112-121. http: //dx.doi.org/10.15294/ijcets.v3i1.8675 Article.

Amalia, N. F., \& Susilaningsih, E. (2014). Pengembangan Instrumen Penilaian Keterampilan Berpikir Kritis Siswa Sma Pada Materi Asam Basa. Jurnal Inovasi Pendidikan Kimia, 8(2), 1380-1389. https://journal.unnes.ac.id/nju/index.php/JIPK/article/viewFile/4443/3807.

Anditiasari, N., \& Dewi, N. R. (2021). Analisis Teori Perkembangan Kognitif Piaget Pada Anak Usia 11 Tahun Di Brebes Piaget's Theory of Cognitive Development Analysis in 11 Year Olds in Brebes. Jurnal Matematika Dan Pendidikan Matematika, 6(1), 97-108. https://doi.org/10.31943/mathline.v6i1.177.

Archer, P. D., Ming, D. W., \& Sutter, B. (2013). The effects of instrument parameters and sample properties on thermal decomposition: interpreting thermal analysis data from Mars. Planetary Science, 2(1), 1-21. https://doi.org/10.1186/2191-2521-2-2.

Arifin, Z., \& Retnawati, H. (2017). Pengembangan instrumen pengukur higher order thinking skills matematika siswa SMA kelas X. PYTHAGORAS: Jurnal Pendidikan Matematika, 12(1), 98. https://doi.org/10.21831/pg.v12i1.14058.

Arini, F. Z. R., Susilaningsih, E., \& Dewi, N. K. (2017). Pengembangan Instrumen Penilaian Proses untuk Mengukur Keterampilan Sains dan Aktivitas Siswa SMP. Journal of Innovative Science Education, 6(2), 170-178. https://doi.org/10.15294/jise.v6i2.19715.

Ayu, P. E. S., Marhaeni, A. A. I. N., \& Adnyana, P. B. (2018). Pengembangan Instrumen Asesmen Keterampilan Belajar Dan Berinovasi Pada Mata Pelajaran IPA SD. PENDASI, 2(2). https://doi.org/10.23887/jpdi.v2i2.2696.

Azizah, N., Wati, M., M., A. S., \& Mahtari, S. (2017). Pengembangan Instrumen Kognitif Keterampilan Proses Sains Siswa SMP pada Materi Pesawat Sederhana. Berkala Ilmiah Pendidikan Fisika, 5(3), 340. https://doi.org/10.20527/bipf.v5i3.3933.

Diani, R. (2015). Pengembangan Perangkat Pembelajaran Fisika Berbasis Pendidikan Karakter dengan Model Problem Based Instruction. Jurnal Ilmiah Pendidikan Fisika Al-Biruni, 4(2), 243-255. https://doi.org/10.24042/jpifalbiruni.v4i2.96.

Gustina, S., Rosidin, U., \& Nyeneng, I. D. P. (2017). Pengembangan Instrumen Performance Assesment Fisika Pada Pembelajaran Laboratorium Berbasis KIT IPA. Jurnal Pembelajaran Fisika, 5(2), 117126. http://jurnal.fkip.unila.ac.id/index.php/JPF/article/view/12490.

Haka, N. B., Hamid, A., Nurhidayah, N., Kesumawardhani, A. D., Rudhini, M., \& Riski, R. A. (2019). Pengembangan Instrumen Evaluasi Two-Tier Multiple Choice Terhadap Literasi Sains Berbantuan Personal Computer. Biosfer: Jurnal Tadris Biologi, 10(2), 201-214. https://doi.org/10.24042/biosfer.v10i2.5755.

Hariono, I., Wiryokusumo, I., \& Fathirul, A. N. (2021). Pengembangan Instrumen Penilaian Kognitif Berbasis Google Form Pelajaran Matematika. Jurnal Kajian Teknologi Pendidikan, 6(1), 57-68. http://dx.doi.org/10.17977/um039v6i12021p057.

Hewi, L., \& Shaleh, M. (2020). Refleksi Hasil PISA (The Programme For International Student Assesment): 
Upaya Perbaikan Bertumpu Pada Pendidikan Anak Usia Dini). Jurnal Golden Age, 4(01), 30-41. https://doi.org/10.29408/jga.v4i01.2018.

Imania, K. A. N., \& Bariah, S. K. (2019). Rancangan Pengembangan Instrumen Penilaian Pembelajaran Berbasis Daring. Jurnal Petik, 5(1), 31-47. https://doi.org/10.31980/jpetik.v5i1.445.

Julianingsih, S., Rosidin, U., \& Wahyudi, I. (2017). Pengembangan Instrumen Asesmen HOTS Untuk Mengukur Dimensi Pengetahuan IPA Siswa di SMP. 5(3), 59-68. http://jurnal.fkip.unila.ac.id/index.php/JPF/article/view/12786.

Krismony, N. P. A., Parmiti, D. P., \& Japa, I. G. N. (2020). Pengembangan Instrumen Penilaian Untuk Mengukur Motivasi Belajar Siswa SD. Jurnal Ilmiah Pendidikan Profesi Guru, 3(2), 249. https://doi.org/10.23887/jippg.v3i2.28264.

Kurniawati, D., \& Mawardi. (2021). Pengembangan Instrumen Penilaian Sikap Gotong Royong dalam Pembelajaran Tematik di Sekolah Dasar. Edukatif : Jurnal Ilmu Pendidikan, 3(3), 640-648.

Lusidawaty, V., Fitria, Y., Miaz, Y., \& Zikri, A. (2020). Pembelajaran IPA Dengan Strategi Pembelajaran Inkuiri Untuk Meningkatkan Keterampilan Proses Sains Dan Motivasi Belajar Siswa Di Sekolah Dasar. Jurnal Basicedu, 4(1), 168-174. https://doi.org/10.31004/basicedu.v4i1.333.

Mahmud, S. N. D., Nasri, N. M., Samsudin, M. A., \& Halim, L. (2018). Science teacher education in Malaysia: challenges and way forward Siti. Asia-Pacific Science Education ORIGINAL, 4(8), 153-155. https://doi.org/10.1186/s41029-018-0026-3.

Mar'atus, S. F., Maharta, N., \& Suana, W. (2018). Pengembangan Instrumen Tes Kemampuan Berpikir Tingkat Tinggi Pada Materi Hukum Newton Tentang Gerak. Journal of Physics and Science Learning, 02(1), 17-26. https://jurnal.uisu.ac.id/index.php/PASCAL/article/view/625.

Meo, L., We'u, G., \& BS, Y. N. (2021). Penerapan Model Pembelajaran Inkuiri Dalam Meningkatkan Hasil Belajar IPA Pada Siswa Sekolah Dasar. Jurnal Ilmiah Pendidikan Citra Bakti, 8(1), 38-52. https://doi.org/10.38048/jipcb.v8i1.97.

Mutmainna, D., Mania, S., \& A. Sriyanti. (2018). Pengembangan Instrumen Tes Diagnostik Pilihan Ganda Dua Tingkat Untuk Mengidentifikasi Pemahaman Konsep Matematika. MaPan, 6(1), 56-69. https://doi.org/10.24252/mapan.2018v6n1a6.

Nafsih, N. Z., Festiyed, F., \& Mufit, F. (2020). Meta Analisis: Pengembangan Instrumen Tes Keterampilan Proses Sains dalam Pembelajaran Fisika dan IPA. Jurnal Penelitian Pembelajaran Fisika, 6(1), 8996. https://doi.org/10.24036/jppf.v6i1.108965.

Nufus, S. H., Gani, A., \& Suhendrayatna. (2017). Pengembangan Instrumen Penilaian Sikap Berbasis Kurikulum 2013 Pada Pembelajaran Kimia SMA. Jurnal Pendidikan Sains Indonesia (Indonesian Journal of Science Education), 5(1), 44-51. http://jurnal.unsyiah.ac.id/JPSI/article/view/8406.

Nuroniyah, S. (2018). Pengembangan instrumen pengukuran sikap tanggung jawab siswa madrasah aliyah. Jurnal Penelitian Dan Evaluasi Pendidikan, 6(2), 134-141. https://doi.org/10.30738/wd.v6i2.3392.

Oktharia, E., Rudibyani, R. B., \& Sofia, E. (2017). Pengembangan Instrumen Asesmen Pengetahuan untuk Mengukur Penguasaan Konsep Siswa. Jurnal Pendidikan Dan Pembelajaran Kimia, 6(1), 74-85. http://jurnal.fkip.unila.ac.id/index.php/JPK/article/view/13033.

Pettersson, L., Ryden, S., Tjäder, I., Rooyackers, O., \& Wernerman, J. (2015). Validation of a point-of-care instrument for bedside glutamine screening in the intensive care unit. Intensive Care Medicine Experimental, 3(S1), 2015. https://doi.org/10.1186/2197-425x-3-s1-a190.

Prananda, G., Saputra, R., \& Ricky, Z. (2020). Meningkatkan Hasil Belajar Menggunakan Media Lagu Anak Dalam Pembelajaran IPA Sekolah Dasar. JURNAL IKA, 8(2), 304-314. https://doi.org/10.36841/pgsdunars.v8i2.830.

Pratiwi, U., \& Fasha, E. F. (2015). Pengembangan Instrumen Penilaian Hots Berbasis Kurikulum 2013 Terhadap Sikap Disiplin. Jurnal Penelitian Dan Pembelajaran IPA, 1(1), 123. https://doi.org/10.30870/jppi.v1i1.330.

Pratiwiningtyas, B. N., Susilaningsih, E., \& Sudana, I. M. (2017). Pengembangan Instrumen Penilaian Kognitif untuk Mengukur Literasi Membaca Bahasa Indonesia Berbasis Model Pirls pada Siswa Kelas IV SD. Journal of Research and Educational Research Evaluation, 6(1), 01-09. https://doi.org/10.15294/jrer.v6i1.16199.

Qureshi, H. A., \& Ünlü, Z. (2020). Beyond the Paradigm Conflicts: A Four-Step Coding Instrument for Grounded Theory. International Journal of Qualitative Methods, 1(9), 1-10. https://doi.org/10.1177/1609406920928188.

Setiawan, H., Sa'dijah, C., \& Akbar, S. (2017). Pengembangan Instrumen Asesmen Autentik Kompetensi Pada Ranah Keterampilan Untuk Pembelajaran Tematik Di Sekolah Dasar. Teori, Penelitian, Dan Pengembangan, 2(7), 874-882. http://dx.doi.org/10.17977/jptpp.v2i7.9602.

Srirahayu, R. R. Y., \& Arty, I. S. (2018). Development of Experiment Performance Assessment To Assess 
Science Process Skills and Cooperation. Jurnal Penelitian Dan Evaluasi Pendidikan, 22(2), 168-181. http://dx.doi.org/10.1088/1742-6596/1233/1/012075.

Sudibyo, E., Nurita, T., Qosyim, A., Sabtiawan, W. B., Surabaya, U. N., \& Kediri, K. (2020). Pendampingan Pengembangan Instrumen Penilaian Berstandar Nasional Bagi Guru IPA SMP Kabupaten Kediri. ABDI, 5(2), 127-133. http://dx.doi.org/10.26740/ja.v5n2.p127-133.

Sudirman, S., Kistiono, K., Akhsan, H., \& Ariska, M. (2020). Pengembangan Instrumen Penilaian Pengetahuan, Sikap Dan Keterampilan Ipa Berbasis Berpikir Kritis Pada Konsep Listrik Siswa Smp. Jurnal Inovasi Dan Pembelajaran Fisika, 7(1), 28-40. https://doi.org/10.36706/jipf.v7i1.10903.

Sylvia, I., Anwar, S., \& Khairani, K. (2019). Pengembangan Instrumen Penilaian Autentik Berbasis Pendekatan Authentic Inquiry Learning Pada Mata Pelajaran Sosiologi di Sekolah Menengah Atas. Jurnal Socius: Journal of Sociology Research and Education, 6(2), 103. https://doi.org/10.24036/scs.v6i2.162.

Tegeh, I. M., \& Kirna, I. M. (2013). Pengembangan Bahan Ajar Metode Penelitian Pendidikan dengan ADDIE Model. Jurnal Pendidikan, 11(1), 16. http://dx.doi.org/10.23887/ika.v11i1.1145.

Tegeh, I. M., Simamora, A. H., \& Dwipayana, K. (2019). Pengembangan Media Video Pembelajaran Dengan Model Pengembangan 4D Pada Mata Pelajaran Agama Hindu. Mimbar Ilmu, 24(2), 158. https://doi.org/10.23887/mi.v24i2.21262.

Vinokurov, A., Geller, D., \& Martin, T. L. (2007). Translation as an Ecological Tool for Instrument Development. International Journal of Qualitative Methods, 6(2), 40-58. https://doi.org/10.1177/160940690700600205.

Wangsa, G. N. A. S., Dantes, N., \& Suastra, I. W. (2021). Pengembangan Instrumen Kemampuan Berpikir Kritis dan Hasil Belajar IPA Kelas V SD Gugus IV Kecamatan Gerokgak. PENDASI: Jurnal Pendidikan Dasar Indonesia, 5(1), 139-150. https://doi.org/10.23887/jurnal_pendas.v5i1.267.

Widiyawati, Y., Nurwahidah, I., \& Sari, D. S. (2019). Pengembangan Instrumen Integrated Science Test Tipe Pilihan Ganda Beralasan Untuk Mengukur HOTS Peserta Didik. Saintifika, 21(2), 1-14. https://jurnal.unej.ac.id/index.php/STF/article/view/13394.

Wirayasa, I. D. G. P., Darmayasa, I. P., \& Satyawan, I. M. (2020). Pengembangan Instrumen Penilaian Hasil Belajar Ranah Kognitif Model 4D Pada Materi Sepak Bola Berdasarkan Kurikulum 2013. Jurnal Pendidikan Jasmani Olahraga Dan Kesehatan, 8(3). http://dx.doi.org/10.23887/jjp.v8i3.33760.

Yoga, P., Sariasa, \& Gunamantha, I. (2020). Pengembangan Instrumen Keyakinan Diri dan Hasil Belajar Matematika Kelas V SD. Jurnal Penelitian Dan Evaluasi Pendidikan Indonesia, 10(1), 31-40. https://doi.org/10.23887/jpepi.v10i1.3507.

Yunita, L., Agung, S., \& Noviyanti, Y. (2017). Penerapan Instrumen Penilaian Ranah Afektif Siswa Pada Praktikum Kimia di Sekolah. Prosiding Seminar Nasional Pendidikan FKIP UNTIRTA, 1(2), $107-$ 114. https://jurnal.untirta.ac.id/index.php/psnp/article/view/107-114 